\title{
CONCLUSION*
}

\author{
Stuart Jenks
}

It is the much-resented privilege of scholars on the cusp of retirement (or rapidly approaching their sell-by date, depending on one's point of view) to write articles mapping out the future course of research. While no one takes much notice of these well-intended pastoral letters, they do have a certain justification. After all, a field in which no one reflects on the research agenda (and the appropriate methodology) is intellectually dead. Moreover, ruminations on 'Where are we? Where should we be heading?' have a certain tradition in Hanseatic research. The founding of the Hanseatic History Association in 1871 witnessed an intense debate about the 'Stand und Aufgaben der Hanseforschung', ${ }^{1}$ Rörig wrote an article with that very title in $1947,{ }^{2}$ Ahasver von Brandt ${ }^{3}$ and Ernst Pitz ${ }^{4}$ offered similar contributions, and in 1993 a conference in Lübeck was convened to look into the same question. ${ }^{5}$ Continuing this tradition is, in my view of it, a challenge to think outside the box, as the felicitous phrase has it, and I propose to take it up.

\section{Networks and the Hanse}

These days, networks are all the rage among historians, but there is still no general agreement on what criteria must be fulfilled before we can properly speak of a 'network'. Indeed, as Mike Burkhardt has pointed out elsewhere, ${ }^{6}$ historians have indiscriminately pasted the label 'network' on all sorts of social structures with the same conspicuous lack of due diligence which rating agencies like Standard \& Poor's displayed when

\footnotetext{
* Many thanks to Rolf Hammel-Kiesow and Albrecht Cordes for critical comments. The responsibility for any remaining errors is mine alone.

1 von Brandt (1970) 3-16 summarizes the debates.

2 Rörig (1950).

3 von Brandt (1973).

4 Pitz (1961).

5 The papers were published in Hammel-Kiesow (2002). See also Selzer and Ewert (2005) 8-18.

${ }^{6}$ Burkhardt (2009) 39-40, cited approvingly by Jahnke (2010) 189 .
} 
scattering AAA ratings hither and yon in the Noughties. To be sure, Stephan Selzer and Ulf Christian Ewert have labored mightily to make the case that the medieval Hanse fits into the theoretical framework of networks and have argued that this is a good explanation of why the Hanse was successful for so long and why it eventually withered away in the seventeenth century. ${ }^{7}$ Deciding whether or not a model roughly seems to fit the historical record is, of course, only the first step in the reception of a theory, and for that purpose it is sufficient to cite suggestive examples, as do Selzer and Ewert. However, the next, essential step is to investigate particular examples intensively and systematically to see just how well the model fits the record in detail. This has been done over and over again for the modern period, ${ }^{8}$ but not yet for the Hanse, with one sterling exception. ${ }^{9}$ This is perhaps just as well, since Hanseatic scholars (and indeed medievalists generally) can profit from the modernists' debate about definitions and methods.

Not only in the context of the Hanse, business networks have been generally understood to be non-hierarchical virtual organizations characterized by iterative business activity. Frequently, these networks were based on pre-existing social networks, be they ethnic (Jews, Cornishmen, Welshmen) or religious minorities (Quakers, Methodists) in the diaspora or united by kinship or by common culture and values (both Hanse). These unifying elements generate a higher level of trust - a central conceptamong members of the business network, which in turn obviates the need for regulation of behavior by formal structures and rules or indeed by contractual obligations among members, who cooperate with one another on a case-by-case basis. Within the network, reliable, but costless information flows from member to member, trust lowers transaction costs and organization costs are minimized. The network solves the agency problem by means of its common values (which discourage free-riding and malfeasance) and multilateral reputation mechanisms (malfeasants are ostracized by all members of the network). The network can also serve as

7 Selzer and Ewert (2001, 2007, 2010a, 2010b).

8 Burt (2003); Pearson, Richardson (2001). See also the critique of Pearson and Richardson by Wilson, Popp (2003) and the response by Pearson, Richardson (2003). All cited articles begin by summarizing the state of play in the debate, so that one gains a good sense of the issues at the centre of the debates. See also the conference reports published by HsozKult (3.2.2010, 3.8.2010, 23.12.2010, 7.2.2011, 6.3.2011). The German conferences (none of whose proceedings have been published) do not seem to have been terribly focussed on the definition of networks.

9 Burkhardt (2009). 
a means of gaining entree to other networks (some member will belong to both) and is itself relatively open to newcomers, if vouched for by a member in good standing.

Now, I am certain that this fumbling attempt at defining networks will cause many a colleague to throw up his hands in horror and begin reciting entire rosaries of exceptions and caveats. That very fact suffices to demonstrate how important it is that we formulate a workaday, pragmatic definition of networks. Absent that, we shall all talk past one another and make no intellectual progress whatsoever, very much the way years of research on 'the crisis of the Middle Ages' - another murky, ill-defined term-did in German medieval studies some years ago.

Here, I would light to highlight a study which constitutes a glowing exception to what I have just written. Burkhardt's dissertation begins with a precise definition of what he understands a network to be. ${ }^{10}$ His investigation of some 900 Lübeck merchants trading with Bergen in Norway during three periods $(1360-1400,1440-70,1490-1510)$ is of great importance for all research on historical networks because it is a long-term study. Consequently, he can observe the development of the Bergenfahrer networks over time, thus fulfilling an central plank of Selzer and Ewert's platform. ${ }^{11}$ Burkhardt makes a revealing distinction between the short-term business contacts of the Bergenfahrer and their companies, which were of middling longevity. While in the late fourteenth century the dicephalous firms (Widerlegung etc.) were largely comprised of kinsmen, this was not true of short-term business contacts, and this was the model which won out in the fifteenth century. Ad hoc, short-term cooperation became more important than longer-term companies, and networks became much looser, albeit more instable. ${ }^{12}$ The same was true of the choice of executors: at the beginning, kinsmen had the upper hand, but testators increasingly chose non-relatives to carry out their last wishes. ${ }^{13}$ Therefore, kinship was no longer the only reliable basis for trust in business or in the salvation of one's soul. ${ }^{14}$ Rather, common culture ('Treu und Glauben') and reputation mechanisms increasingly substituted for kinship, although

10 Burkhardt (2009) 43-54. Note that his definition is much broader than mine and draws heavily on sociological research.

11 Selzer and Ewert (2010) 47. It is worthy of mention that Havila (1996) suggests various models for the dynamic development of three party networks, albeit regarding business practice in the second half of the twentieth century.

12 Burkhardt (2009) 344.

13 Burkhardt (2009) 369 .

14 Pace Selzer and Ewert (2010) 36-7. 
it is also conceivable that the Bergenfahrer had developed a greater appetite for risk.

Burkhardt's study should be read by anyone interested in historical networks, ${ }^{15}$ but it is, as he himself states, ${ }^{16}$ an investigation of just one branch of the trade of just one Hanseatic town. We will have to undertake a number of detailed cases studies before we can be confident of having worked out the specifics of Hanseatic networks. I also suspect that Burkhardt's investigation will prove symptomatic in another way: The closer one looks at one particular case, the more the abstract definitions - be they sociological or historical-will begin to look inadequate. Surely detailed case studies will lead scholars to question and tweak the broad-brush definitions of a historical (business) network. Particularly in regard to the Hanse, it seems to me to be imperative to look very closely indeed at the sources - and we have enough material to hand to do so, starting with merchants' books-and seeing if it is possible to demonstrate, blow-by-blow, how networking actually worked in cases other than that of the Lübeck Bergenfahrer. Can we analyze, say, the accounts and correspondence of the brothers Veckinchusen and specify who was in the networks and how they dealt with one another? Can we pinpoint people whom Hildebrand Veckinchusen trusted more than others? Can we see the insiders cooperating with one another to a higher degree than with outsiders (iterative business activity)? Does information flow more intensely among insiders, and can we see it doing so, for instance in mercantile correspondence? ${ }^{17}$ Are there teaser offers of information, designed to elicit that all-important first response on which one can build trust tit-for-tat? 18

When undertaking case studies, I think it would be a good idea to extend the fringes of networks. To be sure, Selzer and Ewert have suggested that networks share some of the characteristics of von Thünen's rings, ${ }^{19}$ the intensity of networking decreasing as one moves outward from the central partnership through kinsmen, friends and occasional partners. In fact, I think it likely that the networks extended much farther, even if they become much more tenuous towards the edges. It would, for

15 For those who do not read German, there is a detailed English-language summary: Burkhardt (2009) 375-96.

16 Burkhardt (2009) 373 .

17 Lindemann (1978) is no more than a first beginning.

18 A study of the Hanseatic word for trust (gelouwe) would, it seems to me, be rewarding in this context.

19 Selzer and Ewert (2007) 51; (2010a) 45-7. 
instance, be interesting to know if the well-known hostellers in Bruges (and elsewhere), ${ }^{20}$ who demonstrably provided not only lodging and meals, but also warehousing and financial services, were part of the business networks of Hanseatic merchants and provided them with an entree to other networks. While investigating hostellers, we should not neglect brokers and the ubiquitous 'Mr. Fixits' who could be found on many a quayside, offering to facilitate a foreign merchant's trade. ${ }^{21}$ It also seems to me to be worth asking what role mentoring played, not only in the Hanseatic Kontore, but also at the fairs in Frankfurt and Antwerp, in providing merchants with an opportunity to hook up with other networks.

The question of entree deserves to be posed on its own. After all, as Selzer and Ewert imply and Jahnke states explicitly, ${ }^{22}$ network theory explains things reasonably well within the Hanse's trading area, where reputation mechanisms enforced correct behavior and, in so doing, conferred commercial benefits (lower information and transaction costs, less acute agency problems etc.). But merchants outside the Hanse's trading area were not subject to Hanseatic reputation mechanisms, and consequently lack of trust must have arisen and hampered trade. Even if, as Jahnke notes, the Kontore took on the job of social supervision, ${ }^{23}$ this does not explain everything. After all, Hanseatic merchants did not only conduct out-of-area trade in Bergen, Bruges, London and Novgorod. Moreover, the geographical range of Hanseatic trade expanded enormously in the course of the Middle Ages, reaching to Bordeaux, Portugal, Scotland, the Shetlands, Iceland and other places far afield. It would be interesting to ask how the first Hanseatic merchant to set foot in, say, Setúbal or Edinburgh hooked up with the local networks. ${ }^{24}$ The answer, it seems likely to me, will prove to lie in one of three possible points of initial contact which no one seems to have considered yet.

20 Bruges: Murray (2005) 191-205, 210-4. Bordeaux: Stieda (1921) no. 468, p. 46o. There are numerous references to hostellers (wirt) in the Veckinchusen correspondence.

21 Wood (1935) 214-5. 'Translators' may well have played a similar role, and there are surprising numbers of them, if one looks. In the early fifteenth century, for instance, there were Chinese-Arabic translators in Malabar in southwest India (Chaudhury (1985) 99), and the role of Mustafa went well beyond that of a 'translator' fluent in Turkish, Latin and (one presumes) English to William Harborne (Skilliter (1977) 51-6 et passim).

22 Jahnke (2010) 203-5.

23 Jahnke (2010) 205 .

24 For a model of how English merchants broke the ground in new areas, see Jenks (2006) $32-48$. 
- Shipping. Cheap freight rates were the wedge the Hanse drove between Flemish merchants and their English wool suppliers in the late thirteenth century ${ }^{25}$ and provided the Hollanders with a way into the Prussian trade. ${ }^{26}$ Both shippers and sailors enjoyed the right of freeboard, ${ }^{27}$ and they conducted a certain amount of trading even if all the freight-paying cargoes belonged to foreigners, so that there were no insuperable obstacles which prevented a sailor from evolving into merchant. In addition, a perfectly astonishing amount of information was exchanged at the quayside in casual conversation with foreigners. ${ }^{28}$ Consequently, there were ample opportunities to build up commercial contacts with external networks which could be deepened tit-for-tat, if required.

- Pilgrimage. No Christian could possibly object to anyone's transporting pilgrims to Santiago, Rome or the Holy Land by sea. Since ships had to put into port every few days for water and victuals, there were ample opportunities for establishing initial contacts (and gaining detailed knowledge of local products, geography and sea-lanes). In fact, we can point to one concrete example: Transporting pilgrims to Santiago and the Holy Land was demonstrably crucial for Robert Sturmy's reconnaissance of the Mediterranean, which formed the basis for his commercial expedition of $1456 / 57^{29}$

- Emporia. The great fairs in Antwerp, Frankfurt and (later) Leipzig hugely supplemented the opportunities for establishing initial commercial contacts which existed all the year round in large towns (Bruges, London etc.).

However the contacts were established, there can be no doubt that Hanseatic merchants managed to spin a web of contacts to non-Hansards. ${ }^{30}$ Otherwise, prohibiting the foundation of firms with non-Hanseatic merchants and ordering the dissolution of all such mixed companies-which the Diet did five times in the fifteenth century ${ }^{31}$ — would have been completely senseless.

25 Lloyd (1977) 28-49; Lloyd (1991) 38-46.

26 Seifert (1997) 42-4, 89-90, 211.

27 Jenks (2006) 29-30.

28 Jenks (2006) 46.

29 Jenks (2006) 46.

30 Burkhardt (2009) 312-6 presents a handful of such extra-Hanseatic business contacts of the Bergenfahrer.

31 Jenks (1996a) 9-18, 53 . 
Previous research — not only on Hanseatic networks—-has focussed on iterative business activity, but this is not the only way of proving that a network existed. In fact, research into historical networks is much older than its present-day proponents imagine, having started with K.B. McFarlane ${ }^{32}$ and his students in the 1970 os. They, of course, were interested in the English gentry and traced royal and lordly 'affinities' as well as the contours of the 'county community', but these are networks in all but name. I think it would be hugely rewarding to apply the criteria of the McFarlane school to the investigation of Hanseatic networks. Among these are: intermarriage within the group, witnessing one another's charters and wills, functioning as godfather or executor to another member of the group, ${ }^{33}$ serving as a royal officer in the county or as arbitrator in disputes within the group. ${ }^{34}$ To be sure, both Burkhardt and Jahnke have undertaken initial studies along these lines and have called for further investigation, ${ }^{35}$ but were apparently ignorant of the English line of inquiry. A little methodological cross-pollination would seem to be called for here.

\section{Internationality}

As Justyna Wubs-Mrozewicz and Carsten Jahnke have pointed out in this volume, the Hanse has been made to serve the current political agenda over and over again for more than a century, notably the process of German unification and the self-assertion of the nation from 1871 onwards. Hence, the Hanse has tended to be cast as German. ${ }^{36}$ This has engendered a mind-set which induced scholars to make a sharp distinction between the internal and external aspects of the Hanse, a distinction

32 McFarlane initiated matters in 1945 by calling for a broad prosopographical investigation of the English gentry: McFarlane (1981) 36, originally published as 'Bastard Feudalism', BIHR 20 (1945) 161-80.

33 Both of these roles implied an extraordinary degree of trust between principal and nominee. After all, one was committing the eternal salvation of one's child's or one's own soul to another person.

34 I have extracted these criteria from Pollard (1979) and Acheson (1992).

35 Jahnke (2010) 200; Burkhardt (2009) 232-310 does investigate executorship, and adds going surety, membership in the town council and/or in one or more of the various professional groups, benevolent societies and fraternities in late medieval Lübeck to the catalogue.

36 Hammel-Kiesow (2007) has taken another tack and sketched the European aspects of the Hanse, adding much needed critical comments about present day attempts to hijack the medieval Hanse to serve political ends. 
which, as von Brandt has shown, was utterly foreign to those upon whom it was foisted centuries later. ${ }^{37}$ This tendency was strengthened by the fact that, from 1870 at the latest, the Hanse was viewed as a quasi-state which functioned as a proxy for the Empire (and, indeed, for the German People) in the north. If one views the Hanse as an earlier form of the nineteenth-century nation-state, as did Waitz, Höhlbaum, Koppmann and the other early leading lights of Hanseatic historiography, ${ }^{38}$ it is only natural to conceive of it having something on the order of a Home Office and a Foreign Office, the one responsible for internal affairs and the other for relations with foreign powers. It is therefore no surprise that Hanseatic scholarship has produced a considerable number of monographs and articles entitled ' $\mathrm{X}$ and the Hanse', whereby ' $\mathrm{X}$ ' is some 'foreign country'. ${ }^{39}$ These investigations take a distinctly Foreign Office slant, highlighting conflicts, diplomatic correspondence, negotiations and treaties. To be sure, there is nothing wrong with focussing on diplomacy, so long as one recognizes that there was another-commercial-side to the Hanse altogether. It was, however, not until after the collapse of the Second Empire (1918) — which at one stroke removed the political rationale for Hanseatic 'Foreign Office' studies - that Fritz Rörig initiated the investigation of the economic history of the Hanse. ${ }^{40}$

Thus, there was a certain logic to Rörig's call in $195^{\circ}$ for the Europeanization of Hanseatic research ${ }^{41}$ His point was that Hanseatic history is not a marginal phenomenon well off the radar screen of European economic history, but that it lies at its very centre. ${ }^{42}$ Consequently, the economic history of the Hanse needed to be placed firmly in the context of the economic history of Europe as a whole, and Hanseatic historians

37 von Brandt (1962).

38 Jenks (2010) 5, n. 20.

39 For a list of works on 'Holland and the Hanse' see Seifert (1997) 1 n. 4. Of course, Holland was not a 'foreign country' during the period when the Hanse existed and on which these investigations focus: until 1648, Holland, Zealand and the other lordships which were to make up the United Provinces belonged to the Holy Roman Empire and only achieved sovereignty in 1648, at which point the Hanse had just 21 years of life left.

40 von Brandt (1970) 60-1, 65.

41 Rörig (1950).

42 Rörig (1950) 10. It is very curious indeed that Rörig's clarion call in 1950 echoes Waitz' programme of 1871 for Hanseatic history. Waitz insisted that Hanseatic history was central to German history as a whole, so that no history of Germany which ignored the Hanse could be considered adequate. More than that: the Hanse was a driving force of German history: von Brandt (1970) 11-2. If one substitutes 'Europe' for 'Germany', one gets Rörig's views in a nutshell. 
needed to work out its role as a driving force (or a passive subject) of the development of the European economy. ${ }^{43}$

Rörig's agenda failed to produce a well-defined body of literature. Indeed, up until the last generation, scholars continued to emphasize the insularity and singularity of the Hanse. In their view, it was hostile to outsiders (Hollanders, English, South Germans), deploying a variety of instruments (for instance 'guest laws') to regulate-and restrictcommercial contacts between Hansards and non-Hansards ${ }^{44}$ in order to defend its ancient monopoly on trade between East and West against unwelcome competition. ${ }^{45}$ Circling its wagons, the Hanse was implacably hostile to modern business methods. ${ }^{46}$ Compared to the Italians and South Germans, the Hanse was backward. In short, the Hanse increasingly isolated itself from the developing European economy in the late Middle Ages. It was, pace Rörig, marginal.

Although this view has attracted a certain amount of criticism in the last generation, the dragon is not yet dead. ${ }^{47}$ Rather than once again seconding Rörig's call, I would like to focus here on an area which seems ripe for an internationalization discussion: infrastructure.

Infrastructure - very much a new theme in Hanseatic history 48 — would, on the face of it, seem to be the oddest place in the world to look for evidence of internationality. By its very nature, the infrastructure-quays and cranes, roads and bridges and the like-would seem to be wholly local. Nonetheless, there is a good case to be made that, since Hanseatic towns were competing with one another (and other, non-Hanseatic towns) for commercial traffic, they could not afford to let their infrastructure fall much behind international standards. Indeed, there is a good deal of indirect evidence that this was the case. Hanseatic ports financed their infrastructure projects - dredging shipping lanes, setting out buoys, erecting and maintaining landmarks for ships-by a pro rata charge on the merchandise in ships which called at the port or sailed out of it. These charges went under different names-Werkzoll in Hamburg, Pfahlgeld in

43 For a summary of Rörig's views - which were seconded enthusiastically by Heinrich Sproemberg in the 1950s-see Müller-Mertens (2003).

44 For the views of earlier scholars on 'guest law' see Jenks (1996a) 3-9.

45 See Sprandel (1984).

46 The classic indictment is von Stromer (1976).

47 Selzer and Ewert (2007) 64; (2010a) 69 still believe that 'guest law' was used systematically to exclude the Hollanders and other outsiders. Moreover, Gilomen (2010) 362 not only believes this, but also is convinced I believe it too.

48 Ellmers (2005). 
Danzig - but they all created a virtuous circle: the more money a port collected in Werkzoll or Pfahlgeld, the more it could invest in its infrastructure. This attracted more sea-going traffic, which lifted aggregate revenues, allowing for yet more infrastructure investment without a rise in the pro rata charge. However, a port had to make the right sorts of infrastructure investments in order to attract traffic, and those paying the charges were likely to insist on its doing so. Consequently, once a town got beyond very basic measures, there was surely a demand for experts. And if there were internationally sought-after engineers who constructed carp ponds ${ }^{49}$ and the clocks in the towers of town halls, ${ }^{50}$ who pumped the water out of mine-shafts ${ }^{51}$ and planned late medieval Europe's architecturally spectacular churches, then it stands to reason that there must also have been experts who specialized in planning quays and cranes, perhaps even in organizing the topography of docks in order to minimize turn-around times. ${ }^{52}$ If that is the case, then it would be surprising if ideas did not get spread around as the experts travelled from port to port, leading to an observable technical convergence of infrastructures. In other words: a growing internationalization of infrastructure.

However, in my view of it, the invisible infrastructure - which has only just been touched on in Hanseatic research ${ }^{53}$ — was more important than the visible one, and it, too, should be investigated for symptoms of internationalization. The first area where this has been apparent for some time, although not explicitly recognized as such, is weights and measures. While every medievalist is aware of the bewildering complexity of weights and measures, most do not realize that these units travelled with the goods whose quantity they describe as merchandise was traded from region to region. ${ }^{54}$ At every mercantile emporium to which goods were brought from different parts of the medieval world, these disparate systems clashed with one another, as anyone can judge from the numberless conflicts about weights, weighing, scales and the like which are recorded in the Hanseatic Diet's records. From the thirteenth century onwards, these conflicts often enough led to negotiations which, if they

\footnotetext{
49 Hoffmann (1996) 667-9.

50 Dohrn-van Rossum (1985) 323-5.

51 Pars pro toto Schmidt (1970); von Stromer (1984); Bartels (1997). The literature is immense.

52 See Hammel-Kiesow (1996) 17-20 for the topographical organization of Lübeck's harbor.

53 Link, Kapfenberger (2005) 163-8.

54 Witthöft (1979, 1993, 1998).
} 
did not produce a universal system of weights and measures, ${ }^{55}$ at least led to adjustments which nudged the systems until the relevant units stood in an integral relation (e.g. 1:2, 2:3) to one another, which anybody could reckon in his head. In other words, a pragmatic - case by case and product by product -internationalization of weights and measures took place.

To my way of thinking, this suggests that it would be fruitful to search for evidence of internationalization in other areas, and I would like to suggest the legal practice of the time as a promising field of investigation. The observant reader will have noted that I avoid the word 'law'. I have good reasons for doing so, even if German legal historians interested in the Hanse have concentrated on analyzing the codified law of Lübeck and Magdeburg, usually separately. ${ }^{56}$ But the codified law was, as Sofia Gustafsson underscores in her article, intensely conservative and left large and important areas of contemporary commercial practice-such as letters of exchange - apparently unregulated in law for a surprisingly long time. It is therefore only by investigating case law that we can hope to uncover current legal practice. However, case law also disappoints: there are relatively few surviving medieval records of cases tried before the town councillors (in Lübeck law) or the scabini (in Magdeburg law), ${ }^{57}$ and these records contain nary a judgement ${ }^{58}$ which would illuminate current legal practice. I think there is a good reason for the reticence of codified law and the dearth of judgements regarding contemporary commercial practice, namely that disputes about such matters were often settled by arbitration. ${ }^{59}$

55 The only exception is the agreement of $135^{8}$ on a standard size for the tun of herring - the Rostocker Band - which from the late fourteenth century was accepted from East to West in the Hanseatic trading area: Witthöft (1993) 214-7; (1998) 745; Holbach (2005) 144-5.

56 This is true even of Lück (2009), which purports to compare both systems. See also Cordes (2007).

57 For Lübeck law see Ebel, W. (1955), for Magdeburg law see Ebel, F. (1983).

58 For example, Ebel, W. (1955) records no medieval cases in Lübeck which concern letters of exchange. Ebel, F. (1989) no. 320, 324, and (1995) no. 629, contains three medieval cases in which they are mentioned. We learn that it was possible to transfer funds by letter of exchange between Breslau and Thorn, Nuremberg and perhaps also Cracow, but each case turns on the question of whether a debt has been paid, by letter of exchange or otherwise. We learn nothing about legal practice concerning letters of exchange (protests etc.).

59 Gelderblom (2011) 245 notes 'the universal preference for amicable settlement'. By contrast, the central courts established by the Burgundian and Imperial authorities did not attract many commercial cases at all, usually less than a dozen per annum: Gelderblom (2011) 261-64. 
This was demonstrably the case in England, where the vast majority of cases commenced in the central courts never reach[ed] trial'. ${ }^{\prime}$ Suing in King's Bench or Common Bench was, in very many cases, simply a means of putting pressure on an opponent to agree to arbitration and using the machinery of the law to keep him at the negotiating table until the dispute was settled. ${ }^{61}$ Arbitration was common in commercial disputes, whose resolution frequently required specialized knowledge of current market (or maritime) practice and, in some cases, also of foreign languages, which the king's judges did not ordinarily possess. ${ }^{62}$ In comparison to the common law courts, arbitration was also quick and cheap, a powerful recommendation to merchants on the move. Finally, it was usually effective: the parties chose their own arbitrators, but often enough entered into conditioned bonds to abide by their award. ${ }^{63}$

Seemingly unbeknownst to German legal historians, there is quite a substantial amount of Hanseatic source material on arbitration. ${ }^{64}$ Since arbitrators' awards constitute nothing less than case law, indeed with a judgement in the matter at hand, ${ }^{65}$ they provide us with a unique opportunity to explore current legal practice. Better yet, arbitrators in commercial disputes were free to enforce current best practice on the parties, especially when judging in equity. Since they tended to be respected elder merchants with a wealth of experience both at home and abroad, ${ }^{66}$ they surely cannot have neglected their international experience when

60 Baker (1978) 91.

61 Rawcliffe (1991) 100; Powell (1983) 57; (1984) 39.

62 Rawcliffe (1991) 100.

63 Rawcliffe (1991) 109. A conditioned bond is a sealed debt instrument with a condition entered onto the dorse, in this case that the debt bond is null and void if the debtor abides by the award of the arbitrators. In addition, the award might be enrolled, for instance on the dorse of the close roll.

64 UBStL 11 s.v. Schiedsgericht, -richter, -spruch, pp. 420-3; Kuske (1917), vol. 4, p. 513 s.v. Schiedsgericht. I have not overlooked Schöttler (1941), but his J.D. dissertation does not fill the bill, since he is primarily interested in the legal development of arbitration (Schiedsgerichtsbarkeit). Therefore, he often records only the fact of arbitration, but not the material content of the arbitrators' award (12). Furthermore, he has unearthed a mere six cases of arbitration between merchants out of the 209 he analyzes (106).

65 Gelderblom (2011) 248 distinguishes between arbitrators, to whom the conflict parties referred the matter of their own free will and whose judgements, guided by equity, were final, and arbiters, who were appointed by the local courts and followed the prevailing law (depending on the case, this could be local, martime or foreign), but whose judgements could be appealed.

66 In the late seventeenth century, Amsterdam kept registers with the names of respectable and knowledgeable potential arbitrators: Gelderblom (2011) 248. 
arbitrating. ${ }^{67}$ If collected and studied systematically, ${ }^{68}$ arbitrators' awards, I am confident, will show an increasing convergence of legal practice in commercial disputes, that is to say: internationalization. The ubiquity of arbitration, in turn, explains the gaps in the codified law and the dearth of judgements regarding contemporary commercial practice. In a fluid and rapidly changing commercial environment, no one wanted hard-andfast rules. Once a rule was entered into, say, the codex of Lübeck Law, you had to abide by it, but-particularly in the fifteenth, sixteenth and seventeenth centuries-financial innovation was transforming the world of trade rapidly. ${ }^{69}$ Hanseatic towns simply could not afford to be behind the times legally: otherwise their merchants were in for some nasty surprises when they returned home and discovered that the perfectly legitimate deals they had made in Antwerp were actionable in Lübeck or Danzig. There must have been a common legal culture at the highest level of Northern European international trade-which, after all, was the level at which the Hanse operated-, but it cannot have been the fabled lex mercatoria, which was once thought to have been a shadowy body of legal rules, but has been shown to be nothing more than quick legal procedure. ${ }^{70}$ It must rather have been the collective experience of internationally active merchants right across the Baltic and the North Sea, which engendered an acute, and increasingly universal awareness of current best mercantile practice.

\section{Finance}

Finance remains the 'known unknown' of Hanseatic history, to phrase it in terms of Rumsfeldian heuristics. Despite research into financial instruments ${ }^{71}$ and attempts to estimate the balance of payments, ${ }^{72} \mathrm{com}$ paratively little is known about how individual Hanseatic merchants

67 Gelderblom (2011) 247 notes that aribters in cases involving conflicts between natives and foreign merchants were typically mixed, with foreigners and locals serving in equal numbers. In Bruges, for instance, the privileges granted to the English in 1359 mandated arbitration of Anglo-Flemish by two Englishmen and two Flemings.

68 One should not limit the search to Hanseatic archives. There is a wealth of Hanseatic material in foreign archives, notably in London, Bruges and Brussels, Antwerp and Amsterdam: Gelderblom (2011).

69 van der Wee (1967).

70 Baker (1986) 346; Cordes (2003) from the perspective of German legal history.

71 Neumann (1863); Peters $(1976,1977)$; North (1991) 816-24.

72 Sprandel (1975). 
financed their trade. The question is, however, crucial since there is general scholarly agreement that banking and finance were generally very underdeveloped in the medieval Hanseatic world ${ }^{73}$ and that consequently liquidity was scarce. The fact that Hanseatic merchants had to transfer liquidity over vast distances between purchase and sale of goods only exacerbated the problem. Given that we are reasonably well informed on the financial instruments Hansards used (letters of exchange, overkop, bills obligatory etc.), it seems time that we turned our attention to how individual merchants organized liquidity in conducting their businesses. ${ }^{74}$ There are two aspects of this which might well repay investigation. The first is the most obvious: using merchant's accounts to reconstruct a time line of purchases and sales and correlating that to acquisitions and transfers of liquidity by means of loans and letters of exchange respectively. The second is less obvious: tracing a merchant's portfolio strategy over his lifetime. As Lübeck merchants' wills reveal, they tended to gather their assets closer to home as they grew older. ${ }^{75}$ Clearly expecting to die sooner rather than later, they liquidated their assets far afield and acquired easily liquidated assets close to home (urban and rural real estate, ${ }^{76}$ urban rents of various kinds, debts owing, plate etc. $)^{77}$ in order to make the task of their executors as simple as possible. In short, they reduced the geographical scattering and increased the liquidity of the assets in their portfolios. Clearly, this portfolio management must have had effects on other merchants, as liquidity was withdrawn from trade, and these would seem to me to be worth pursuing.

At the end of the Hanse's history, the founding of the Hamburg Bank (1619) — at the request of the English Merchant Adventurers and Sephardic immigrants from the Netherlands ${ }^{78}$ and very much on the model of the Amsterdam Wisselbank-provides us with a new possibil-

73 North (1991), 815, 817, echoing von Stromer (1976) 208-10. To my knowledge, no one has systematically studied the 'exchange booths' (Wechselstuben), which von Stromer (1979) identified as fulfilling bank functions in Germany south of the Main and west of the Rhine, for the Hanse's trade area. Needless to say, it would repay investigation.

74 Jenks (2010) is only a very modest first stap in this direction.

75 This is, of course, only clear if a merchant makes more than one will, but many did, for instance John van Hachede on 5 June 1355, 25 May 1356 and 19 July 1359: von Brandt (1973) No. 560, 594, 784.

76 Earlier scholars interpreted this as an expression of the merchants' desire to 'rise into the nobility', but I am, needless to say, extremely sceptical.

77 On the types of assets Lübeck merchants of the sixteenth century named in their wills, see Pelus (1993).

78 Kellenbenz (1958) 253-9. 
ity of investigating the financing of Hanseatic trade. Even if most of the bank's records have been lost, ${ }^{79}$ some do survive in later copies, including a list of the merchants who had accounts in 1619. Since Hamburg's merchants were required to transact all commercial payments over 400 mark banco via the bank and cash all letters of exchange over 400 Lübeck marks through it, ${ }^{80}$ the loss of the Bank's accounts is grievous, as they could tell us much about how Hamburg's trade was financed in the last 50 years of the Hanse's history. Nonetheless, it might well be worthwhile to triangulate surviving records of the Wisselbank of Amsterdam (founded 16o9), 81 the Hamburg Bank and the Nuremberg Banco publico ${ }^{82}$ (founded 1621) and see what light they cast on the financing of Hanseatic trade.

\section{Logistics}

On 15 June 2006 The Economist published a special report 'A Survey of Logistics' celebrating the fiftieth anniversary of the invention of the container, which among other things optimized the utilization of scarce shipping space and led, in turn, to the design of large sea-going vessels specifically designed to transport a maximum number of 'twenty-foot equivalents', not to mention flat-bed railway cars and lorries. The upshot was that freight rates dropped dramatically (to $2.74 \%$ of their previous level), a vital pre-condition for today's globalized supply chains. Today, component manufacturing can take place wherever it is most economic, because it is cheap, easy and quick to transfer TFEs from ship to rail to road and deliver the required parts just-in-time.

The problem of how to utilize scarce space in transporting goods and optimize the transfer of merchandise from one form of transport to another was not unknown to the medieval Hanse. ${ }^{83}$ While shipping times were dictated by the weather and the dates of the major fairs, leaving no significant room for optimization, the same was not true of the utilization of space. Theoretically, shippers and freighters should have tried to fit as much cargo onto a ship as it could hold and remain seaworthy. Moreover, the late Middle Ages witnessed the standardization of some

\footnotetext{
79 Sieveking (1934) 125 .

80 Peters (1995a) 154.

81 van Dillen (1925) publishes some early records of the Amsterdam Wisselbank.

82 Peters (1995b).

83 Ellmers (2005) kicked off the discussion of the second problem.
} 
shipping containers — e.g. the Rostocker Band for herring ${ }^{84}$ — and a steady increase in the size of the largest ships, loosely coupled with the introduction of new ship types (hulk, caravel). Eventually, some ships got to be so large that they could no longer lay to at the quayside, but had to go to anchor well before the port and be unloaded by lighter. The construction of cranes made unloading large containers easier if the ship could be brought to quayside (which argued for large containers), but unloading large containers from big ships into small, rocking lighters could be very awkward (which argued for small containers). In short, shippers and maritime architects had a number of opportunities to re-think the relationship between freight containers and the space available on board. ${ }^{85}$

Now, of course, the ship-building plans of medieval maritime architects no longer survive, and the ships they built have, with very few exceptions, long since rotted away, but there are sources (customs accounts, lists of ships and cargoes lost or taken at sea) which, properly interpreted, ought to give us some insight into the logistical thinking of the Middle Ages. Hitherto, these sources have been used to calculate a ship tonnages or the volume of ships' holds, and that, in turn, required scholars to determine the metric volume and weight of medieval measures. ${ }^{86}$ I think it would be worthwhile to take another slant on the sources and ask which packing units were customarily associated with which products. ${ }^{87}$ Then one could investigate whether particular packing units were associated with particular forms of transport. An example: On 20 January 1478, William Weston transported 3 fardels of cloth from London to Plymouth on 3 horses. ${ }^{88}$ Clearly, a fardel was fundamentally a horse-load, even if the packing unit was retained when the same goods were transported by sea: That only means that the cloth was not re-packed for export.

84 On this and parallel processes see Holbach (2005) 144-5.

85 There is some evidence that this, in fact, went on. On 9 Feb. 1497, the Bruges Kontor complained to Lübeck that the Antwerp customers were demanding double customs on copper, furs, flax, English and Flemish cloth and wax because they had determined that the normal packing units (e.g. a stro of wax) contained between one third more and double the amount of merchandise as had been customary: HR IV 3 , No. 735. For the Diet's reaction see HR IV 4, No. $79 \S 60-3,80-83$. Many thanks to Rolf Hammel-Kiesow for this reference.

86 Wolf (1986), citing earlier scholarship. See also Witthöft (1979).

87 I have made a modest start in this direction in the index of matters to the Danzig customs accounts for 1409 and 1411: Jenks (2006), Sachregister s.v. Maße und Gewichte. There I listed alphabetically the products for which a particular packaging unit was standard, e.g. a vat was the packaging unit for alum, pottash, cotton, beer etc.

88 TNA: PRO, E122/194/22 $\mathrm{m}$ 10. The 'one horse, one fardel' rule is general in the London customs accounts: If goods are transported on horseback, there is always one fardel per horse. 
The customs accounts are not the only sources to shed light on the customary packing units for various products. Although it would be impossible to give a complete list, a few examples may suffice to show the breadth of source material available. Schedules of local tolls in medieval England, for instance, often enough set the charges according to the packing unit, ${ }^{89}$ and the same is true of many customs schedules, for example in England $(1507)^{90}$ and Hamburg (1606). ${ }^{91}$ Finally, trading companies' statutes may yield information on packing units, be it in international or in regional trade: one example is the Merchant Adventurers' prohibition of retail trade for its members (1608). ${ }^{92}$

The obvious next question to ask would be if the associations between packing units and particular products change over time. That should yield some information of the logistics of the supply chain up to the point of sea transport.

The supply chain is worth investigating in its own right, since this is an integral part of today's logistics. Immense cost savings can be effected by minimizing inventory and having components delivered just in time for manufacturing, but getting things just right requires a high degree of forward thinking and supply chain control. ${ }^{93}$ I would suggest that this also held true, to a certain degree, for the medieval Hanse. After all, if you want to deliver wood in Danzig at midsummer, ${ }^{94}$ someone has to chop a tree down in the autumn, the wood needs to be seasoned, transported, stacked and so forth. Here, too, the supply chain has to be managed. Indeed, one might be forgiven for thinking that, given the slowness of communication in the medieval era, supply chain management was more, rather than less difficult, and the logistical complexity of the putting-out system - the most modern and efficient mode of production known to medieval manwas of another order of magnitude altogether. ${ }^{95} \mathrm{~A}$ certain amount of work has been done, notably by Link on Prussian grain ${ }^{96}$ and Kapfenberger on

89 Masschaele (2007) 156-6o.

90 Gras (1918) 694-706.

91 Pitz (1961a) 202-75.

92 Lingelbach (1902) 111-4.

93 The Economist (15.6.2006), Special Report.

94 See Heß, Link, Sarnowsky (2008) 58, No. 145 for one example.

95 Holbach (1994).

96 Link (2004) 18-29. Link's doctoral thesis on the same subject, completed under the direction of Jürgen Sarnowsky (Hamburg) and entitled Der preußische Getreideexport im 15. Jahrhundert. Seine Bedeutung und Einbettung in die nordeuropäische Wirtschaft, has been completed and should appear in the series Quellen und Darstellungen zur hansischen Geschichte next year. 
wood, ${ }^{97}$ but more light could be shed on the logistics of supply chain management in the Middle Ages.

\section{Probability Theory, Bayesian Statistics and the Hanse}

At some point in the early Noughties, Thomas Griffiths and Joshua Tenenbaum, professors of cognitive science at Brown and MIT respectively, asked test subjects to answer a series of questions involving predictions on the basis of a single piece of information. ${ }^{98}$ Among the questions were:

1. 'Insurance agencies employ actuaries to make a prediction about people's life spans - the age at which they will die-based upon demographic information. If you were assessing an insurance case for an 18-year-old man, what would you predict for his life span?'

2. 'If you made a surprise visit to a friend, and found that they had been watching a movie for 30 minutes, what would you predict for the length of the movie?'

3. 'Imagine you hear about a movie that has taken in $\$ 10$ million at the box office, but you don't know how long it has been running. What would you predict for the total amount of box office intake for that movie?'

4. 'If your friend read you her favourite line of poetry and told you it was line 5 of a poem, what would you predict for the total length of the poem?'

5. 'If you heard a member of the House of Representatives had served for 15 years, what would you predict his total term in the House would be?'

6. 'If you opened a book about the history of ancient Egypt to a page listing the reigns of the pharaohs, and notice that at $4000 \mathrm{BC}$ a particular pharaoh had been ruling for 11 years, what would you predict for the total duration of his reign?'

7. 'Imagine you are in somebody's kitchen and notice that a cake is in the oven. The timer shows that it has been baking for 35 minutes. What would you predict for the total amount of time the cake needs to bake?'99

97 Kapfenberger (2003) 16-21.

98 Griffiths, Tenenbaum (2006) 770.

99 Griffiths, Tenenbaum (2006) 770. I have rearranged the order to conform with the results and discussion in Griffiths, Tenenbaum (2006) 769-70. 
The questions were formulated to test people's ability to draw strong inferences from sparse data, in this case exactly one piece of data. The predictions of the test subjects were then compared to those of an optimal Bayesian model, by which a probability distribution is computed from the product of a prior probability (the test subject's rough idea of how things work) and the net likelihood of occurrence of a particular event. Taking the example of the insurance company, actuarial data shows that people in the US die at an average age of 75 , with a standard deviation of 16 years, and that age distribution around the mean is more or less Gaussian. ${ }^{100}$ The predictive value of this data is limited: although the Gaussian distribution is the correct model, it only tells you that $95 \%$ of all people can be expected to die between the ages of 59 and 91 (75 \pm 16$)$. If you use the model to make a prediction about a particular person sitting in front of you desiring to buy life insurance, the prediction depends on a particular piece of data, namely the age of that person at the moment. If that person is 18,39 or 51 , you will probably guess that he or she will live to around 75 . If that person is 75 at the moment, then you will probably predict that he or she will live a few more years at least. If the customer is 96, you would not expect him or her to live much longer. ${ }^{101}$ In fact, you have shifted the Gaussian normal distribution curve to the right for the last two customers. This is the particular value of Bayesian statistics: it combines a prior model (the Gaussian distribution of age at death with a mean of 75 years) with a particular piece of data (the age of the customer at the moment) to make a robust prediction.

The results of Griffiths and Tenenbaum's experiment showed that people combined the correct statistical model of distribution for each particular case with the data given in the question to make predictions which 'were indistinguishable from optimal Bayesian predictions based on empirical prior distributions' on questions $1,23,4$ and 5 . On question 6 (pharaohs) people guessed slightly too high, because they assumed that ancient Egyptians lived longer than they in fact did (i.e. they used an erroneous parameter). Correcting for that error brings the observed test results into line with the Bayesian optimum. Even when the empirical

100 For non-statisticians: The standard deviation is the average distance of any observation from the average (mean) of all observations. The normal or Gaussian distribution is bell-shaped, with $95 \%$ of all observations falling within the range plus or minus twice the standard deviation.

101 This is a paraphrase of Griffiths, Tenenbaum (2006) 768. 
distribution was irregular, as in the case of cakes in the oven (question 7), test subjects were close to the ideal Bayesian predictions.

The test results showed that people intuitively used the correct statistical model of distribution, although the empirically observed distributions were Gaussian (questions 1 and 2), power-law ${ }^{102}$ (questions 3 and 4), Erlang $^{103}$ (questions 5 and 6) and irregular (question 7). Even when test subjects had no direct experience of the phenomenon in question, they could arrive at the correct statistical distribution model by making an analogy with something more familiar to them. If errors arose, they did so not because people used the wrong distribution model, but because they were mistaken about the mean value. That means that one can turn the experiment around and use the test subjects' guesses to identify the statistical distribution model which they are applying.

The observant reader will have guessed where this is leading. The medieval Hanse had two arrows in its quiver: trade boycotts and war. ${ }^{104}$ Both were intended to drive the Hanse's opponent to the negotiating table by putting pressure on him by withdrawing trade or attacking his shipping, but neither could be employed on the basis of anything but incomplete knowledge. That meant that for the duration of the conflict the Hanse was constantly balancing two questions: How long can our opponent hold out? How long can we maintain the pressure? The answer to both questions was uncertain: the Hanse knew very little about the confidential discussions in foreign government circles even in peace time ${ }^{105}$ and could know even less about the economic damage its boycott was causing. ${ }^{106}$ Worse

102 In a power-law (exponential) distribution, the shape of the curve recording the observations is determined by a single quality called $\lambda$ (not, as in the Gaussian distribution, by the mean and the standard deviation), with the mean equalling the standard deviation. That means that the curve is symmetrical around a $45^{\circ}$ line drawn from 0,0 (in the lower left-hand corner of the graph) into outer space and has a parabolic shape like your satellite receiver. This sounds complicated, but it's easy if you think about movie grosses: most movies don't make very much money at all, but a few movies make gazillions, so the distribution curve is almost shaped like an " $\mathrm{L}$ ".

103 The Erlang distribution is a non-symmetric distribution which is difficult to explain and has a dismayingly complex formula. Suffice it to say that-under the assumptions Griffiths, Tenenbaum (2006) 768 n. 2, 773-are using, it looks like the flight path of a skijumper as he comes off the ramp: quickly up in the air, then a long glide down to zero.

104 On Hanseatic attitudes to war and peace see Jenks (1996b) 53-9.

105 Even the Bruges Kontor (which should have had the best connections of any Hanseatic institution) was completely flummoxed by the Burgundian revaluation of the groat in 1409: Jenks (1982) 318.

106 The first step in declaring a trade boycott was to prohibit contact with the opponent: Jenks (1996a) 53-9. 
yet, news of embargo violation by its own merchants was uncertain, partial and delayed. ${ }^{107}$ Some conflicts ended quickly (the war of the Cologne confederation against Denmark in 1367), while others dragged on for years (the boycott of Bruges 1451-57). Sometimes the Hanse won, sometimes it lost and sometimes it was rescued by exogenous events which turned the tables in its favor in a way nobody could have foreseen (the conflict with England 1469-74). Clearly, the Hanse miscalculated from time to time, but was always forced to act under the constraint of imperfect information. In short, trade boycotts and wars tested the Hanse's ability to draw strong inferences from sparse data.

This seems to me to be a striking parallel to the situation of Griffiths and Tenenbaum's test subjects, and it would be fascinating to explore the possibility of building up a mathematical model of the Hanse's continuing deliberations about conflicts using Bayesian statistics. Needless to say, I can see many objections to this, the most important of which is that we do not have independent empirical evidence from which to calculate an optimal Bayesian prediction, which is, of course, the essential pre-condition for judging the accuracy of strong inferences drawn from sparse data, and we certainly cannot travel back in time to ask Hans Castorp how long he thought a given blockade would last, given that it had been in force for ' $\mathrm{x}$ ' number of years. ${ }^{108}$ Even so, it ought to be possible to deduce which distribution model the Diet used. And who knows? Maybe Bayesian statistics and prediction under conditions of uncertainty and imperfect information may lead us to other questions...

At the end, however, a note of caution. The use of theoretical models by historians is only justified on one of two grounds: either the model explains sources which we could not explain satisfactorily before, or the

107 Shortly after the Hanse proclaimed a trade embargo against England, Danzig claimed the embargo was being violated by Deventer and other towns on the Lower Rhine, while the Bruges Kontor complained that Danzig was violating it: Jenks (1992) vol. 2, 730.

108 At the risk of handing my own hangmen the rope and erecting my own scaffold, I refer the reader to Sokal, Bricmont (1998), who rightly villify those who hold 'forth at length on scientific theories about which [they have], at best, an exceedingly hazy idea', who import 'concepts from the natural sciences into the humanities or social sciences without giving the slightest conceptual or empirical justification' and who display 'a superficial erudition by shamelessly throwing around technical terms in a context where they are completely irrelevant': Sokal, Bricmont (1998) 4. Those who want to pursue Bayesian statistics are referred to O'Hagan, West (2010). A much simpler introduction is Perfors et al. (2011). Other articles marrying Bayesian statistics and human cognitive science which would repay study are Griffiths, Baraff, Tenenbaum (2004); Krynski, Tenenbaum (2003); Tenenbaum, Griffiths, Kemp (2006) and Baker, Tenenbaum, Saxe (2006). 
model gives us new - and fruitful — questions to ask of the sources. If neither of these conditions is fulfilled, it is our job to take the theory out behind the barn and kill it with an axe.

\section{Bibliography}

\section{Unpublished Sources}

The National Archives (Kew, Surrey), PRO, E122/194/22

\section{Published Sources}

von Brandt, A. ed. (1973) Regesten der Lübecker Bürgertestamente des Mittelalters. Band II: 1351-1363, Veröffentlichungen zur Geschichte der Hansestadt Lübeck 24 (Lübeck: 1973). van Dillen, J.G. ed. (1925) Bronnen tot de geschiedenis der wisselbanken van Amsterdam, Delft, Middelburg en Rotterdam, Rijks Geschiedkundige Publicatiën groote reeks 59-6o, 2 vols. (The Hague 1925).

Ebel, F. ed. (1983) Magdeburger Recht I: Die Rechtssprüche für Niedersachsen, Mittelniederdeutsche Forschungen 89/I (Köln: 1983).

__. (1989) Magdeburger Recht II: Die Rechtsmitteilungen und Rechtssprüche für Breslau, Mitteldeutsche Forschungen 89/II/1 (Köln: 1989).

—_. (1995) Magdeburger Recht II: Die Rechtsmitteilungen und Rechtssprüche für Breslau, Mitteldeutsche Forschungen 89/II/2 (Köln: 1995).

Ebel, W., ed. (1955) Lübecker Ratsurteile, 4 vols. (Göttingen: 1955-67).

Heß, C., Link, C. and J. Sarnowsky eds. (2008) Schuldbücher und Rechnungen der Großschäffer und Lieger des Deutschen Ordens in Preußen. Band 1: Großschäfferei Königsberg I (Ordensfoliant 141), Veröffentlichungen aus den Archiven Preußischer Kulturbesitz 62, 1 = Quellen und Darstellungen zur hansischen Geschichte NF 59,1 (Köln: 2008).

Jenks, S. ed. (2006) Robert Sturmy's Commercial Expedition to the Mediterranean (1457/8), Bristol Record Society Publication 58 (Bristol: 2006).

Kuske, B. ed. (1917) Quellen zur Geschichte des Kölner Handels und Verkehrs im Mittelalter, Publikationen der Gesellschaft für Rheinische Geschichtskunde 33, 4 vols. (Bonn: 192334; repr. Düsseldorf: 1978).

Lingelbach, W.E. (1902) The Merchant Adventurers of England, Their Laws and Ordinances with Other Documents, University of Pennsylvania Translations and Reprints, 2nd series 2 (Philadelphia: 1902).

Skilliter, S.A. (1977) William Harborne and the Trade with Turkey 1578-1582. A documentary study of the first Anglo-Ottoman relations (Oxford: 1977).

UBStL Urkundenbuch der Stadt Lübeck (Codex diplomaticus Lubecensis, Abt. 1), 11 vols. (Lübeck: 1843-1932).

\section{Secondary Literature}

Acheson, E. (1992) A Gentry Community. Leicestershire in the Fifteenth Century, c. 1422-c. 1485, Cambridge Studies in Medieval Life and Thought, 4th series, 19 (Cambridge: 1992).

Baker, J.H. ed. (1978) The Reports of Sir John Spelman. Volume II, Publications of the Selden Society 94 (London: 1978).

—_. (1986) 'The Law Merchant and the Common Law before 1700', in J.H. Baker, The Legal Profession and the Common Law. Historical Essays, History Series 48 (London: 1986) 34168 (originally published Cambridge Law Journal 38 (1979) 295-322).

Baker, C.L., Tenenbaum, J.B. and R.R. Saxe (2006) 'Bayesian models of human action understanding', Advances in Neural Information Processing Systems 18 (2006) 99-106. 
Bartels, C. (1997) 'Strukturwandel in Montanbetrieben des Mittelalters und der frühen Neuzeit in Abhängigkeit von Lagerstättenstrukturen und Technologie', in Gerhard, H.-J. ed., Struktur und Dimension. Festschrift für Karl Heinrich Kaufhold zum 65. Geburtstag, 2 vols. (Stuttgart: 1997) vol. 1, 26-70.

von Brandt, A. von (1972) Die Hanse und die nordischen Mächte im Mittelalter, Arbeitsgemeinschaft für Forschung des Landes Nordrhein-Westfalen, Geisteswissenschaften 102 (Köln: 1962), repr. in Friedland, K. and R. Sprandel eds., Lübeck, Hanse, Nordeuropa. Gedächtnisschrift für Ahasver von Brandt (Köln: 1979) 13-36.

—_. (1963) 'Die Hanse als mittelalterliche Wirtschaftsorganisation-Entstehung, Daseinsformen, Aufgaben', in Die Deutsche Hanse als Mittler zwischen Ost und West, Wissenschaftliche Abhandlungen der Arbeitsgemeinschaft für Forschung des Landes Nordrhein-Westfalen 27 (Köln: 1963).

—. (1970) 'Hundert Jahre Hansischer Geschichtsverein. Ein Stück Sozial- und Wissenschaftsgeschichte', Hansische Geschichtsblätter 88:1 (1970) 3-67.

Burkhardt, M. (2010) Der hansische Bergenhandel im Spätmittelalter. Handel一KaufleuteNetzwerke, Quellen und Darstellungen zur hansischen Geschichte NF 6o (Köln: 2009).

Burt, R. (2003) 'Freemasonry and business networking during the Victorian period' Economic History Review 56:4 (2003) 657-88.

Chaudhuri, K.N. (1985) Trade and Civilisation in the Indian Ocean. An Economic History from the Rise of Islam to $175^{\circ}$ (Cambridge: 1985).

Cordes, A. (2003) 'The search for a medieval Lex mercatoria', Oxford University Comparative Law Forum at http://ouclf.iuscomp.org/articles/cordes.shtml (2003).

- ed. (2007) Hansisches und hansestädtisches Recht, Hansische Studien 17 (Trier: 2007).

Dohrn-van Rossum, G. and R. Westheider (1985) 'Die Einführung der öffentlichen Uhren und der Übergang zur modernen Stundenrechnung in den spätmittelalterlichen Städten Niedersachsens', in Meckseper, C. ed., Stadt im Wandel. Kunst und Kultur des Bürgertums in Norddeutschland, 4 vols. (Stuttgart: 1985) vol. 4, 317-35.

Ellmers, D. (2005) 'Die Seehäfen der Hanse als Dienstleistungszentren eines weitgespannten Transportnetzes', Hansische Geschichtsblätter 123 (2005) 109-28.

Gelderblom, O. (2011) 'The Resolution of Commercial Conflicts in Bruges, Antwerp, and Amsterdam (1250-1650)', in Ma, D. and J. Luiten van Zanden eds., Law and Long-Term Economic Change: A Eurasian Perspective (Stanford: 2011) 244-76.

Gilomen, H.-J. (2010) 'Netzwerke im europäischen Handel des Mittelalters-Versuch einer Bilanz', in Fouquet, G. and H.J. Gilomen eds., Netzwerke in europäischen Handel des Mittelalters, Vorträge und Forschungen 72 (Ostfildern: 2010) 341-64.

Gras, N.S.B. (1918) The Early English Customs System. A Documentary Study of the Institutional and Economic History of the Customs from the Thirteenth to the Sixteenth Century (Cambridge MA: 1918).

Griffiths, T.L., Baraff, E.R. and J.B. Tenenbaum (2004) 'Using Physical Theories to Infer Hidden Causal Structure', Proceedings of the Twenty-Sixth Annual Conference of the Cognitive Science Society (2004) 500-5, also available at http://cocosci.berkeley.edu/tom/ papers/hidden.pdf and http://csjarchive.cogsci.rpi.edu/Proceedings/2004/CogScio4.pdf.

Griffiths, T.L. and J.B. Tenenbaum (2006) 'Optimal Predictions in Everyday Cognition', Psychological Science 17:9 (2006) 767-73.

Hammel-Kiesow, R. (1996) 'Der Lübecker Hafen bis zur Mitte des 19. Jahrhunderts. Infrastruktur, Handelsgüter und Handelsvolumen', in Der Lübecker Hafen ab Mitte des 19. Jahrhunderts bis in die heutige Zeit [exposition catalogue] (Lübeck: 1996) 14-27, 181-3.

- - ed. (2002) Vergleichende Ansätze in der hansischen Geschichtsforschung, Hansische Studien 13 (Trier: 2002).

—_. (2007) 'Europäische Union, Globalisierung und Hanse. Überlegungen zur aktuellen Vereinnahmung eines historischen Prozesses', Hansische Geschichtsblätter 125 (2007) 1-44. 
Havila, V. (1996) International Business-Relationship Triads. A Study of the Changing Role of the Intermediating Actor, Företagsekonomiska Institutionen Uppsala Universitet doctoral thesis no. 64 (Uppsala: 1996).

Hoffmann, R.C. (1996) 'Economic Development and Aquatic Ecosystems in Medieval Europe' American Historial Review 101:3 (1996) 631-69.

Holbach, R. (1994) Frühformen von Verlag und Großbetrieb in der gewerblichen Produktion (13.-16. Jahrhundert), Vierteljahrschrift für Sozial- und Wirtschaftsgeschichte Beiheft 110 (Stuttgart: 1994).

- (2005) 'Hansische Versandlogistik: Das Böttcherhandwerk', Hansische Geschichtsblätter 123 (2005) 129-52.

HSozKult (3.2.2010) hsozkult.geschichte.hu-berlin.de/tagungsberichte/id=2892.

- (3.8.2010) hsozkult.geschichte.hu-berlin.de/tagungsberichte/id=3226.

- (23.12.2010) hsozkult.geschichte.hu-berlin.de/tagungsberichte $/ \mathrm{id}=3454$.

- (7.2.2011) hsozkult.geschichte.hu-berlin.de/tagungsberichte/id=3533.

- (6.3.2011) hsozkult.geschichte.hu-berlin.de/termine/id=15907.

Jahnke, C. (2010) 'Handelsnetze im Ostseeraum', in Fouquet, G. and H.-J. Gilomen eds., Netzwerke im europäischen Handel des Mittelalters, Vorträge und Forschungen 72 (Ostfildern: 2010) 189-212.

Jenks, S. (1982) 'War die Hanse kreditfeindlich?', Vierteljahrschrift für Sozial- und Wirtschaftsgeschichte 69:3 (1982) 305-38.

- (1992) England, die Hanse und Preußen. Handel und Diplomatie, 1377-1474, Quellen und Darstellungen zur hansischen Geschichte NF 38, 3 vols. (Köln: 1992).

—_. (1996a) 'Zum hansischen Gästerecht', Hansische Geschichtsblätter 114 (1996) 3-6o.

—_. (1996b) 'Friedensvorstellungen der Hanse (1356-1474)', in Fried, J. ed., Träger und Instrumentarien des Friedens im hohen und späten Mittelalter, Vorträge und Forschungen 43 (Sigmaringen: 1996) 405-39.

—_. (2010) 'Die Finanzierung des hansischen Handels im Spätmittelalter am Beispiel von Preußen', Hansische Geschichtsblätter 128 (2010) 1-18.

Kapfenberger, D. (2003) Holz und Holzhandel in Preußen von 1399-1409, StaatsexamenThesis (Erlangen: 2003).

Kellenbenz, H. (1958) Sephardim an der unteren Elbe. Ihre wirtschaftliche und politische Bedeutung vom Ende des 16. bis zum Beginn des 18. Jahrhunderts, Vierteljahrschrift für Sozial- und Wirtschaftsgeschichte Beiheft 40 (Wiesbaden: 1958).

Krynski, T.R., and J.B. Tenenbaum (2003) 'The role of causal models in reasoning under uncertainty', Proceedings of the Twenty-Fifth Annual Conference of the Cognitive Science Society (2003) 693-8, also available at http://csjarchive.cogsci.rpi.edu/Proceedings/2003/ pdfs/140.pdf.

Lindemann, M. (1978) Nachrichtenübermittlung durch Kaufmannsbriefe. Brief-"Zeitungen" in der Korrespondenz Hildebrand Veckinchusens (1398-1428), Dortmunder Beiträge zur Zeitungsforschung 26 (München: 1978).

Link, C. (2004) Getreidehandel in Preußen am Anfang des 15. Jahrhunderts, MA-Thesis (Erlangen: 2004).

Link, C. and D. Kapfenberger (2005) 'Transaktionskostentheorie und hansische Geschichte: Danzigs Seehandel im 15. Jahrhundert im Licht einer volkswirtschaftlichen Theorie', Hansische Geschichtsblätter 123 (2005) 153-68.

Lloyd, T.H. (1977) The English Wool Trade in the Middle Ages (Cambridge: 1977).

- (1991) England and the German Hanse, 1157-1611. A study of their trade and commercial diplomacy (Cambridge: 1991).

Lück, H., Puhle, M. and A. Ranft eds. (2009) Grundlagen für ein neues Europa. Das Magdeburger und Lübecker Recht im Spätmittelalter und Früher Neuzeit, Quellen und Forschungen zur Geschichte Sachsen-Anhalts 6 (Köln: 2009).

Masschaele, J. (2007) 'Toll and Trade in Medieval England', in Armstrong, L, Elbl, I. and M.M. Elbl eds., Money, Markets and Trade in Late Medieval Europe. Essays in Honour of John H.A. Munro, Later Medieval Europe 1 (Leiden: 2007) 146-83. 
McFarlane, K.B. (1973) The Nobility of Later Medieval England. The Ford Lectures for 1953 and Related Studies (Oxford: 1973).

—. (1981) England in the Fifteenth Century. Collected Essays (London: 1981).

Müller-Mertens, E. (2003) 'Die Hanse in europäischer Sicht. Zu den konzeptionellen Neuansätzen der Nachkriegszeit und zu Rörigs Konzept', in Müller-Mertens, E. and H. Böcker eds., Konzeptionelle Ansätze der Hanse-Historiographie, Hansische Studien 14 (Trier: 2003) 19-43.

Murray, J.M. (2005) Bruges, Cradle of Capitalism, 1280-1390 (Cambridge: 2005).

Neumann, M. (1863) Geschichte des Wechsels im Hansagebiete bis zum 17. Jahrhundert nach archivalischen Urkunden (Erlangen: 1863).

North, M. (1991) 'Banking and Credit in Northern Germany in the Fifteenth and Sixteenth Centuries', in Banchi pubblici, banchi privati e monti di pietà nell'Europa preindustriale. Amministrazione, tecniche operative e ruoli economici. Atti del convegno Genova, 1-6 ottobre 1990 (Genoa: 1991) 809-26.

O'Hagan, A. and M. West eds. (2010) The Oxford Handbook of Applied Bayesian Analysis (Oxford: 2010).

Pearson, R. and D. Richardson (2001) 'Business networking in the industrial revolution', Economic History Review 54:4 (2001) 657-79.

- (2003) 'Business networking in the industrial revolution: riposte to some comments', Economic History Review 56:2 (2003) 362-8.

Pelus, M.-L. (1993) 'Investitionsformen in Lübeck und ihre Rolle in der Vermögensbildung', in Jenks, S. and M. North eds., Der hansische Sonderweg? Beiträge zur Sozial- und Wirtschaftsgeschichte der Hanse, Quellen und Darstellungen zur hansischen Geschichte NF 39 (Köln: 1993) 95-108.

Perfors, A. et al. (2011) 'A tutorial introduction to Bayesian models of cognitive development', forthcoming in Cognition, available at http://cocosci.berkeley.edu/tom/papers/ cogdevtutorial.pdf.

Peters, I.-M. (1976) 'Das mittelalterliche Zahlungssystem als Problem der Landesgeschichte', Blätter für deutsche Landesgeschichte 112 (1976) 139-83.

_- (1977) 'Das mittelalterliche Zahlungssystem als Problem der Landesgeschichte (Teil II.)', Blätter für deutsche Landesgeschichte 113 (1977) 141-202.

Peters, L.F. (1995a) 'Hamburger Bank', in North, M. ed., Von Aktie bis Zoll. Ein historisches Lexikon des Geldes (München: 1995) 154-5.

_- (1995b) 'Banco Publico', in North, M. ed., Von Aktie bis Zoll. Ein historisches Lexikon des Geldes (München: 1995) 31-2.

Pitz, E. (1961) 'Hansische Geschichtsforschung 1945-1960', Vierteljahrschrift für Sozial- und Wirtschaftsgeschichte 48 (1961) 251-62.

—. ed. (1961a) Die Zolltarife der Stadt Hamburg, Deutsche Handelsakten des Mittelalters und der Neuzeit 11 = Deutsche Zolltarife des Mittelaters und der Neuzeit 2 (Wiesbaden: 1961).

Pollard, A.J. (1979) 'The Richmondshire Community of Gentry during the Wars of the Roses', in Ross, C. ed., Patronage, Pedigree and Power in Later Medieval England (Gloucester: 1979) 37-59.

Powell, E. (1983) 'Arbitration and the Law in England in the Late Middle Ages', Transactions of the Royal Historical Society, 5th series, 33 (1983) 49-67.

- (1984) 'Settlement of Disputes by Arbitration in Fifteenth-Century England', Law and History Review 2:1 (1984) 21-43.

Rawcliffe, C. (1991) '“That Kindliness Should be Cherished More, and Discord Driven Out": the Settlement of Commercial Disputes by Arbitration in Later Medieval England', in Kermode, J. ed. Enterprise and Individuals in Fifteenth-Century England (Stroud: 1991).

Rörig, F. (1950) 'Stand und Aufgaben der Hansischen Geschichtsforschung' Hansische Geschichtsblätter 69 (1950) 1-13.

Schmidt, U. (1970) Die Bedeutung des Fremdkapitals im Goslarer Bergbau um 1500, Beiträge zur Geschichte der Stadt Goslar 27 (Goslar: 1970). 
Schöttler, R. (1941) Die Schiedsgerichtsbarkeit unter der Deutschen Hansa in der Zeit von 1232 bis 1495, jur. Diss. Münster (Bochum: 1941).

Seifert, D. (1997) Kompagnons und Konkurrenten. Holland und die Hanse im späten Mittelalter, Quellen und Darstellungen zur hansischen Geschichte NF 43 (Köln: 1997).

Selzer, S. and U.C. Ewert (2001) 'Verhandeln und Verkaufen, Vernetzen und Vertrauen. Über die Netzwerkstruktur des hansischen Handels', Hansische Geschichtsblätter 119 (2001) 135-61.

—_. (2005) 'Die Neue Institutionenökonomik als Herausforderung an die Hanseforschung', Hansische Geschichtsblätter 123 (2005) 7-29.

—. (2007) 'Netzwerkorganisation im Fernhandel des Mittelalters: Wettbewerbsvorteil oder Wachstumshemmnis?' in Berghoff, H. and J. Sydow eds., Unternehmerische Netzwerke. Eine historische Organisationsform mit Zukunft? (Stuttgart: 2007) 45-70.

- (2010a) 'Wirtschaftliche Stärke durch Vernetzung. Zu den Erfolgsfaktoren des hansischen Handels', in Häberlein, M. and C. Jeggle eds., Praktiken des Handels. Geschäfte und soziale Beziehungen europäischer Kaufleute in Mittelalter und früher Neuzeit, Irseer Schriften NF 6 (Konstanz: 2010) 3-69.

—. (2010b) 'Netzwerke im europäischen Handel des Mittelalters. KonzepteAnwendungen-Fragestellungen', in Fouquet, G. and H.-J. Gilomen eds., Netzwerke im europäischen Handel des Mittelalters, Vorträge und Forschungen 72 (Ostfildern: 2010) $21-47$.

Sieveking, H. (1919) 'Zum 300. Jahrestag der Gründung der Hamburger Bank', Zeitschrift des Vereins für hamburgische Geschichte 23 (1919) 52-82.

_- (1934) 'Die Hamburger Bank', in van Dillen, J.G. ed., History of the Principal Public Banks, Contributions to the History of Banking 1 (The Hague: 1934) 125-6o.

Sokal, A. and J. Bricmont (1998) Intellectual Impostures. Postmodern philosophers' abuse of science (London: 1998).

Sprandel, R. (1975) Das mittelalterliche Zahlungssystem nach hansisch-nordischen Quellen des 13.-15. Jahrhunderts, Monographien zur Geschichte des Mittelalters 10 (Stuttgart: 1975).

—_. (1984) 'Die Konkurrenzfähigkeit der Hanse im Spätmittelalter', Hansische Geschichtsblätter $102(1984) 21-38$.

von Stromer, W. (1976) 'Der innovatorische Rückstand der hansischen Wirtschaft', in Schulz, K. ed., Beiträge zur Wirtschafts- und Sozialgeschichte des Mittelalters. Festschrift für Herbert Helbig zum 65. Geburtstag (Cologne: 1976) 204-17.

_. (1979) 'Funktion und Rechtsnatur der Wechselstuben als Banken', Bankhistorisches Archiv, Zeitschrift zur Bankengeschichte (1979: 1) 3-34.

_ _. (1984) 'Wassersnot und Wasserkünste im Bergbau des Mittelalters und der frühen Neuzeit', in Kroker, W. and E. Westermann eds., Montanwirtschaft Mitteleuropas vom 12. bis 17. Jahrhundert. Stand, Wege und Aufgaben der Forschung (Bochum: 1984).

Tenenbaum, J.B., Griffiths, T.L. and C. Kemp (2006) 'Theory-based Bayesian models of inductive learning and reasoning', Trends in Cognitive Sciences 10:7 (2006) 309-18.

van der Wee, H. (1967) 'Anvers et les innovations de la technique financière aux XVI et XVII ${ }^{\mathrm{e}}$ siècles', Annales E.S.C. 22 (1967) 1067-89.

Wilson, J.F. and A. Popp (2003) 'Business networking in the industrial revolution: some comments', Economic History Review 56:2 (2003) 355-61.

Witthöft, H. (1979) Umrisse einer historischen Metrologie zum Nutzen der wirtschafts- und sozialgeschichtlichen Forschung. Maß und Gewicht in Stadt und Land Lüneburg, im Hanseraum und im Kurfürstentum/Königreich Hannover vom 13. bis zum 19. Jahrhundert, Veröffentlichungen des Max-Planck-Instituts für Geschichte 6o/1-2, 2 vols. (Göttingen: 1979).

- (1993) 'Zeichen, Verpackung, Maß/Gewicht und Kommunikation im hansischen Handel', in Jenks, S. and M. North eds., Der hansische Sonderweg? Beiträge zur Sozial- und Wirtschaftsgeschichte der Hanse, Quellen und Darstellungen zur hansischen Geschichte NF 39 (Köln: 1993) 203-24. 
Witthöft, H. (1998) 'Wägen und Messen', in Bracker, J. et al. eds., Die Hanse. Lebenswirklichkeit und Mythos, 2nd ed. (Lübeck: 1998) 739-49.

Wolf, T. (1986) Tragfähigkeiten, Ladungen und Maße im Schiffsverkehr der Hanse vornehmlich im Spiegel Revaler Quellen, Quellen und Darstellungen zur hansischen Geschichte NF 31 (Köln: 1986).

Wood, A.C. (1935) A History of the Levant Company (Oxford: 1935; repr. London: 1964). 